\title{
Addition of mancozeb to the fungicide mixtures DMI + QoI and SDHI + QoI on the control of wheat leaf blights
}

\author{
Erlei Melo Reis ${ }^{1}$, Mateus Zanatta ${ }^{2}$ e Carlos Alberto Forcelini ${ }^{3}$
}

\begin{abstract}
${ }^{1}$ Facultad de Agronomia, Universidad de Buenos Aires, Av. San Martín 4453, C1417DSE, Argentina; ${ }^{2}$ Agroservice -Pesquisa e consultoria agrícola - Rua Miguel Vargas, 291, Passo Fundo - RS, Brasil, CEP 99035-380; ${ }^{3}$ Universidade de Passo Fundo - Faculdade de Agronomia, Universidade de Passo Fundo, Bairro São José, Passo Fundo - RS, Brasil, CEP 99052-900
\end{abstract}

Autor para correspondência: Erlei Melo Reis (erleireis@upf.br)

Data de chegada: 28/04/2017. Aceito para publicação em: 13/07/2017.

$10.1590 / 0100-5405 / 179192$

\begin{abstract}
Reis, E. M.; Zanatta, M.; Forcelini, C.A. Addition of mancozeb to the fungicide mixtures DMI + QoI and SDHI + QoI on the control of wheat leaf blights. Summa Phytopathologica, v.45, n.1, p.23-27, 2019.

Wheat leaf blights caused by Drechslera siccans, D. tritici-repentis, especially $D$. tritici-repentis, are difficult to be controlled by site-specific fungicide mixtures. Due to development of resistance, the use of double site-specific mixtures has shown control inferior to $50 \%$. In an experiment conducted in the field with the wheat cultivar Jadeite 11, in $3 \times 6$ m plots and four replicates, the effect of a muli-site fungicide added to fungicide mixtures on the control of leaf blights was evaluated. The effect of the following mixtures was evaluated: picoxystrobin + cyproconazole, kresoximmethyl + epoxiconazole, azoxystrobin + cyproconazole, pyraclostrobin + epoxiconazole, pyraclostrobin + fluxapyroxad, trifloxystrobin + prothioconazole and azoxystrobin + propiconazole, added of five mancozeb levels, $0 ; 1.5 ; 2.0 ; 2.5$ and $3.0 \mathrm{~kg} / \mathrm{ha}$. The first application occurred after $30 \%$

leaf incidence, and the remaining two occurred at 15 and 18-day intervals. The fungicides were applied with a backpack sprayer pressurized by $\mathrm{CO}_{2}$, delivering $180 \mathrm{~L} / \mathrm{ha}$. Leaf blights severity was quantified, control was calculated, the percentage of chlorophyll in flag leaves was determined, and grain yield was assessed. The mean control of leaf blights by the mixtures without addition of the multi-site fungicide was $44 \%$. The disease severity reduced as a function of the addition of mancozeb levels for all treatments. Control superior to $80 \%$ was obtained with the mixtures kresoxim methyl + epoxiconazole and pyraclostrobin + epoxiconazole, both added at least $2.0 \mathrm{~kg} / \mathrm{ha}$ mancozeb. There was a positive reflex on the increase in wheat grain yield as a function of control, varying from $3005 \mathrm{~kg} / \mathrm{ha}$ for the best treatment to $2026 \mathrm{~kg} / \mathrm{ha}$ for control.
\end{abstract}

Keywords: Drechslera siccans, D. tritici-repentis, manganese ethylene-bis-dithiocarbamate, triazoles, strobilurins, carboxamides.

\section{RESUMO}

Reis, E. M.; Zanatta, M.; Forcelini, C.A. Adição de mancozebe às misturas de fungicidas IDMs + IQes e IQes + ISDHs no controle das manchas foliares do trigo. Summa Phytopathologica, v.45, n.1, p.23-27, 2019.

As manchas foliares do trigo causadas por Drechslera siccans e, principalmente, $D$. tritici-repentis são de difícil controle pelas misturas de fungicidas sítio específicos. Devido ao desenvolvimento da resistência, o uso das misturas duplas de sítio específicos apresenta controle inferior a 50\%. Em experimento conduzido no campo com a cultivar de trigo Jadeíte 11, parcelas de $3 \times 6 \mathrm{~m}$, com quatro repetições, avaliou-se o efeito da adição de fungicida multi sítio às misturas de fungicidas no controle das manchas foliares. Foi avaliado o efeito das misturas picoxistrobina + ciproconazol, cresoxim metílico + epoxiconazol, azoxistrobina + ciproconazol, piraclostrobina + epoxiconazol, piraclostrobina + fluxapiroxada, trifloxistrobina + protioconazol e azoxistrobina + propiconazol adicionadas de cinco doses de mancozebe, $0 ; 1,5 ; 2,0 ; 2,5$ e 3,0 $\mathrm{kg} / \mathrm{ha}$. A primeira aplicação foi feita após o afilhamento com $30 \%$ de incidência foliar e as outras duas com intervalos de 15 a 18 dias. Os fungicidas foram aplicados com pulverizador costal e pressão gerada por $\mathrm{CO}_{2}$ e vazão de 180 $\mathrm{L} /$ ha. Foi quantificada a severidade foliar das manchas, calculado o controle, determinado o percentual de clorofila nas folhas-bandeiras e o rendimento de grãos. A média do controle das manchas foliares pelas misturas sem adição do fungicida multi sítio foi de $44 \%$. A severidade da doença foi reduzida em função da adição de doses do mancozebe em todos os tratamentos. Controle superior a $80 \%$ foi obtido com as misturas de cresoxim metílico + epoxiconazol e piraclostrobina + epoxiconazol, ambas adicionadas de no mínimo 2,0 kg/ha de mancozebe. Houve reflexo positivo no aumento do rendimento de grãos do trigo em função do controle, variando de $3005 \mathrm{~kg} /$ ha no melhor tratamento e $2026 \mathrm{~kg} / \mathrm{ha}$ na testemunha.

Palavras-chave: Drechslera siccans, D. tritici-repentis, etilenobisditiocarbamato de manganês, falha de controle, triazóis, estrobilurinas, carboxamidas.

The annual consumption of wheat (Triticum aestivum L.) in Brazil is estimated at 11 million tons. According to Conab (1), the national production of wheat in 2015 growing season was 5,971 million tons. The difference between consumption and demand is supplied by imports.

The most common diseases caused by fungi in wheat are powdery mildew, leaf rust, leaf blights, fusarium head blight, and blast (6).

Leaf blights are caused by the necrotrophic fungi Bipolaris sorokiniana (Ito \& Kurib.) Drechsler ex Dastur, Drechslera siccans (Died.) Schoem., D. tritici-repentis (Died.) Schoem, while Stagonospora nodorum (Berk) Berk. Drechslera spp. are predominant in southern Brazil $(6,9,11)$.

Yellow spot symptoms begin with a dark brown spot of approximately $1 \mathrm{~mm}$ in diameter, which then evolve presenting a prominent yellow halo of elliptical shape that increases in size reaching up to $1.0 \mathrm{~cm}$ in length. The dark brown central spot scarcely evolves in size and remains distinct until the senescence of leaves. When the 
green leaf area is completely killed by the disease, the dark spots, which marked the infection site, are still identifiable. In plants with all dead leaves, the symptoms of dark central point in the center of the spot and yellowish yellow halo are visible in the still green leaf sheaths.

The causal agents of leaf blights have as common characteristic the transmission by seeds and, saprophytically survive in crops residues after harvests. In southern Brazil, complete wheat residue decomposition takes place in 18 months (7).

Damage due to leaf blights caused by Drechslera spp. can reach up to $45 \%$ and can be assessed by $y=1000-6.5$ LI function, where ' $y$ ' is the grain yield normalized to $1,000 \mathrm{~kg} / \mathrm{ha}$ and LI is the leaf incidence (8).

Control measures against leaf blights include seed production in fields under crop rotation, seed treatment with fungicides and efficient levels of fungicides applied to aerial organs. The time for the first application is defined based on the economic damage threshold and the remaining applications should occur at 15 days intervals (8).

From 2004 season, farmers and farm advisers have complained about the difficulty in controlling wheat leaf blights by using fungicides. Some authors $(11,12)$ have shown that the reduced sensitivity of Drechslera spp. to strobilurins and triazoles, except for pyraclostrobin, may explain the control failure.

Mean control of wheat leaf blights has been less than $50 \%$. Such low efficiency indicates that the fungicide application cost is not covered and has a negative effect on wheat grain yield (10).

We hypothesized that, due to the reduced sensitivity of the fungus to site-specific fungicides, addition of a non-penetrating, multi-site, protectant fungicide can improve the control of wheat leaf blights, which nowadays is only $50 \%$.

This study aimed to quantify the effects of the addition of a protectant/multisite fungicide to the co-formulations currently used to control wheat leaf blights.

\section{MATERIAL AND METODS}

The present study was conducted in the experimental field of the Faculty of Agronomy of University of Passo Fundo (latitude 28 $13^{\circ}$ 'S, longitude $52^{\circ} 23^{\prime} \mathrm{W}$ and altitude $687 \mathrm{~m}$ a.s.l.) from June to December 2015 .

The wheat cultivar Jadeite 11, susceptible to leaf spot, was grown in no-tillage and under crop rotation with black oats (Avenas trigosa Schreb.) cultivated in the previous winter and seeded on June 29, 2015.

Seeds were treated with the insecticides imidacloprid (Gaucho) and fipronil + pyraclostrobin (Standak Top) $0.1 \mathrm{~L}+0.2 \mathrm{~L}$ for $100 \mathrm{~kg}$ seeds, respectively.

Modus, a plant growth regulator, $200 \mathrm{~mL} / \mathrm{ha}$, was applied at growth stage GS 32 (13). The other cultural treatments were applied according to the technical recommendations (8).

Fertilization: $300 \mathrm{~kg} / \mathrm{ha}$ of the formulated fertilizer 05-20-20 (N-P $\left.\mathrm{O}_{5}-\mathrm{K}_{2} \mathrm{O}\right)$ was applied in the sowing furrows. Nitrogen application was carried out by using Super N, $350 \mathrm{~kg} / \mathrm{ha}$ (33\% N and $22 \% \mathrm{~S})$, at the first visible node, GS 31 (13).

The following fungicides were assessed in the field: epoxiconazole $(16 \%)+$ pyraclostrobin $(26 \%)$ (Abacus SC $-300 \mathrm{~mL} / \mathrm{ha})$, cyproconazole $(8 \%)+$ picoxystrobin $(20 \%)$ (Aproach Prima - $300 \mathrm{~mL} / \mathrm{ha})$, azoxystrobin $(30 \%)+$ benzovindiflupyr $(15 \%)$ (Elatus $-200 \mathrm{~mL} / \mathrm{ha})$, prothioconazole $(17.5 \%)+$ trifloxystrobin $(15 \%)($ Fox SC - $500 \mathrm{~mL} / \mathrm{ha})$, epoxiconazole $(12.5 \%)+$ kresoxim methyl $(12.5 \%)($ GuapoSC -600 $\mathrm{mL} / \mathrm{ha})$, fluxapyroxad $(16.7 \%)+$ pyraclostrobin $(33.3 \%)$ (Orkestra SC
- $300 \mathrm{~mL} / \mathrm{ha}$ ), cyproconazole $(8 \%)+$ azoxystrobin (20\%) (Priori Xtra SC $300 \mathrm{~mL} / \mathrm{ha})$, azoxystrobin $(25 \%)+$ propiconazole $(25 \%)$ (Priori + Tino $-500 \mathrm{~mL} / \mathrm{ha}$ ), added of mancozeb at $0,1.5,2.0,2.3$, and $3.0 \mathrm{~kg} /$ ha) (Unizeb Gold 75 WG).

Three applications were programmed: the first one was at the stem elongation stage (GS 33: third node visible); the second application was at the booting stage (GS 41: flag leaf sheath expanding), and the third application was at anthesis (GS 61: anthesis beginning). The interval between applications was 17 days between the first and the second application, 14 days between the second and the third application and 21 days between the third and the fourth application.

Sprayings were carried out by using a precision backpack sprayer with constant pressure by $\mathrm{CO}_{2}$ gas. The boom was equipped with four DG TeeJet ${ }^{\circledR} 110015$ nozzles spaced $0.5 \mathrm{~m}$ apart. The applied water volume was $180 \mathrm{~L} / \mathrm{ha}$. For the spraying, the boom was positioned at 40 $\mathrm{cm}$ above the plant canopy for complete and uniform foliar coverage

Experimental design was factorial, considering five mancozeb levels x eight co-formulation (DMI, QoI, and SDHI) mixtures in a completely randomized block design (DBC), plots of $2.21 \times 6.0 \mathrm{~m}$ and four replicates.

Leaves containing lesions were collected and taken to the laboratory, where a humid chamber of leaf segments was prepared. Such material was kept in acrylic boxes ( $11 \times 11 \times 2.5 \mathrm{~cm}$ in height) containing, at the bottom, a 5-mm nylon foam layer covered with Whatman filter paper no. 4 , and maintained at $25^{\circ} \mathrm{C}$ and $12 \mathrm{~h}$ photoperiod. One hundred lesions were analyzed under a stereoscopic microscope (60x magnitude) after 48-hour incubation.

Three leaves from the top of the main stem of 10 plants /plot were collected and, in the laboratory, severity ( 0 to $100 \%$ ) was assessed.

The relative chlorophyll content was measured by using a chlorophyll meter (SPAD-502, Minolta, and Osaka, Japan) (4), which estimates the percentage of chlorophyll in the leaf blade. Readings were made on 20 flag leaves per plot.

Grain yield was obtained by harvesting with a Wintersteiger plot machine, $8.2 \mathrm{~m}^{2}$, on November 23 .

Data underwent analysis of variance and treatment means were compared according to Tukey's test at 5\% for severity and according to Duncan's test at $5 \%$ for grain yield. The relationship between grain yield and mancozeb rates was determined.

\section{RESULTS AND DISCUSSION}

In the experimental area, leaf blights occurred naturally. Plots that were not sprayed (control) with fungicide showed $72 \%$ severity. The incidence of fungi causing leaf blight was $60 \% \mathrm{D}$. tritici-repentis and $4 \%$ B. sorokiniana.

Leaf blight severity after treatments. Plots treated with the mixtures, without addition of mancozeb, showed severity of $18 \%$ for epoxiconazole + pyraclostrobin, $26 \%$ for fluxapyroxad + pyraclostrobin, $28 \%$ for epoxiconazole + kresoxim methyl, $34 \%$ for prothioconazole + trifloxystrobin, $34 \%$ for azoxystrobin + propiconazole, $39 \%$ for cyproconazole + picoxystrobin, and $62 \%$ for azoxystrobin + benzovindiflupyr (Table 1 ). The high severity after treatments, without addition of the protectant, evidences the difficulty in controlling leaf blights with these mixtures $(10,12)$. This shows the reduction in sensitivity of $D$. tritici-repentis to DMIs + QoIs, and QoI + SDHI.

On the other hand, considering the overall means for mancozeb 
effect, the severity reduced when the protectant was added to all mixtures. The average severity using the mixtures was 36, 28, 25, 22 and $21 \%$ for $0.0,1.5,2.0,2,2$ and $3 \mathrm{~kg} /$ ha mancozeb, respectively (Table 1).

Wheat plots treated with epoxiconazole + pyraclostrobin added by 2.5 and $3.0 \mathrm{~kg} /$ ha mancozeb showed the lowest leaf spot severity: 5 and $4 \%$, respectively (Table 1 ).

The overall control mean was 50,61, 65, 69 and $70 \%$ for mancozeb added at the levels $0,1.5,2.0,2.5$ and $3.0 \mathrm{~kg} / \mathrm{ha}$, respectively (Table 2 ). The control mean by the co-formulations alone was $50 \%$. This is considered very low and does not equalize the fungicide application cost.

Control greater than $80 \%$ was obtained by adding $1.5,2.0,2.5$ and $3.0 \mathrm{~kg} / \mathrm{ha}$ mancozeb to epoxiconazole + pyraclostrobin, 2.0, 2.5 to $3.0 \mathrm{~kg} / \mathrm{ha}$ mancozeb to epoxiconazole + methyl kresoxim and 2.5 to $3.0 \mathrm{~kg} /$ ha mancozeb to prothioconazole $(17.5 \%)+$ trifloxystrobin (15\%) (Table 2).

The mixtures with the least response to mancozeb addition were cyproconazole $(8 \%)+$ azoxystrobin $(20 \%)$, showing maximum control of $53 \%$, and azoxystrobin + benzovindiflupyr with control of $51 \%$ (Table 2).

An important tool against the development of fungal resistance is the addition of multi-site protectant fungicides, such as mancozeb, as reported by Gisi et al. (3) and confirmed in our study.

It has often been observed that the application of some fungicides such as pyraclostrobin and mancozeb results in a more intense green leaves color of treated plants (2). Reis \& Floss (8) showed that the effect of fungicides (maneb and mancozeb) on increasing green color in wheat was due to manganese uptake by the wheat leaves.

The lowest chlorophyll content was shown by the mixtures applied without addition of mancozeb, i.e. cyproconazole ( $8 \%)+$ azoxystrobin $(20 \%)$ and with $30 \%$ the highest for epoxiconazole + pyraclostrobin with $45 \%$. On the other hand, the mixture that showed the highest response of the addition of mancozeb in increasing the chlorophyll content was kresoxim methyl + epoxiconazole with 48, 48, 49 and $50 \%$ of chlorophyll at $1.5,2,0,2.5$ and $3.0 \mathrm{~kg} / \mathrm{ha}$ of mancozeb, respectively (Table 3 ).

Table 1. Effect of the addition of mancozeb to triazole, strobilurin and carboxamid mixtures on leaf blight severity. Jadeíte 11 wheat cultivar. Passo Fundo, 2015.

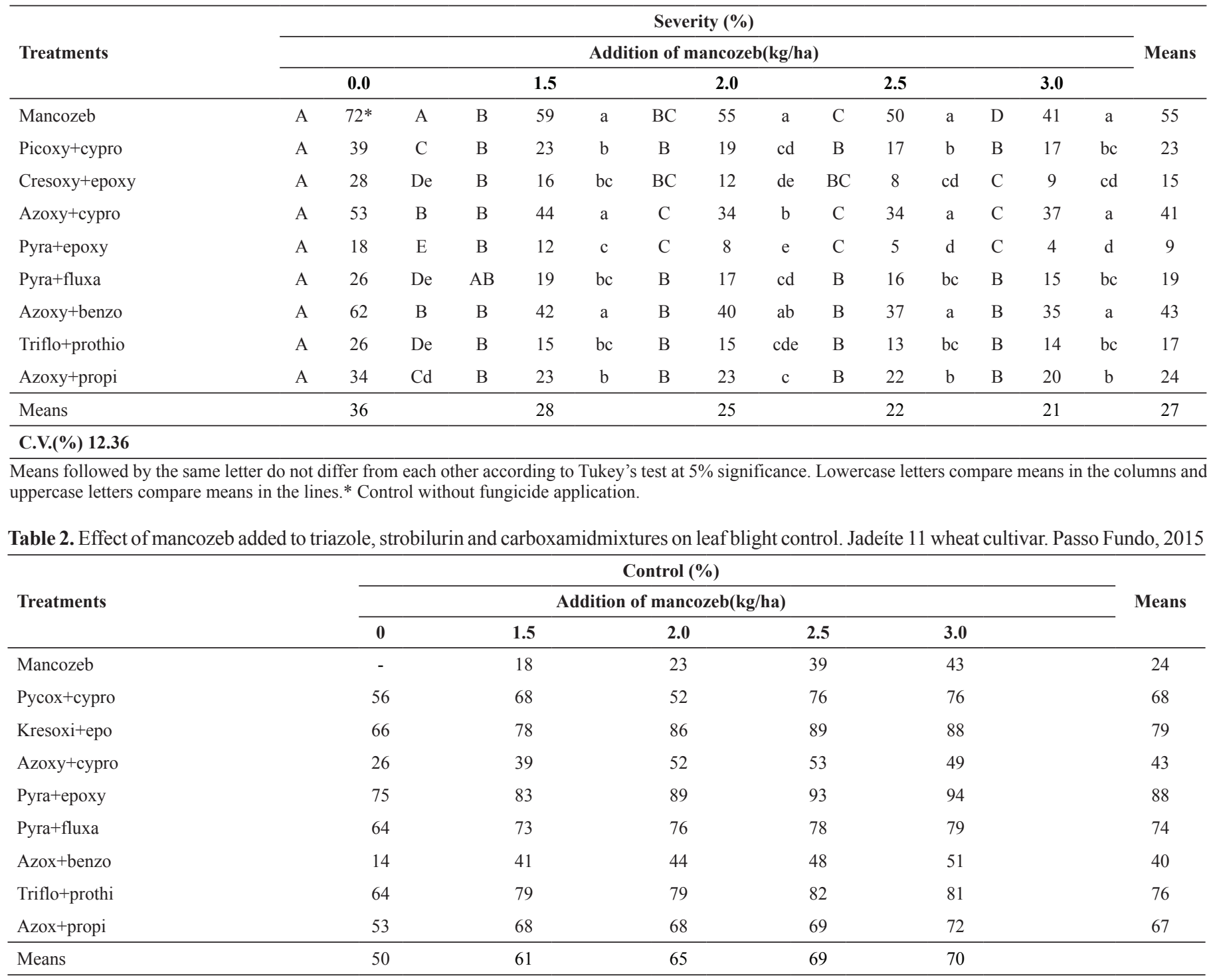

Control without fungicide application, $72 \%$ severity. 
Table 3. Effect of mancozeb on the chlorophyll content in wheat leaves. Wheat Jadeite 11 cultivar. Passo Fundo, 2015

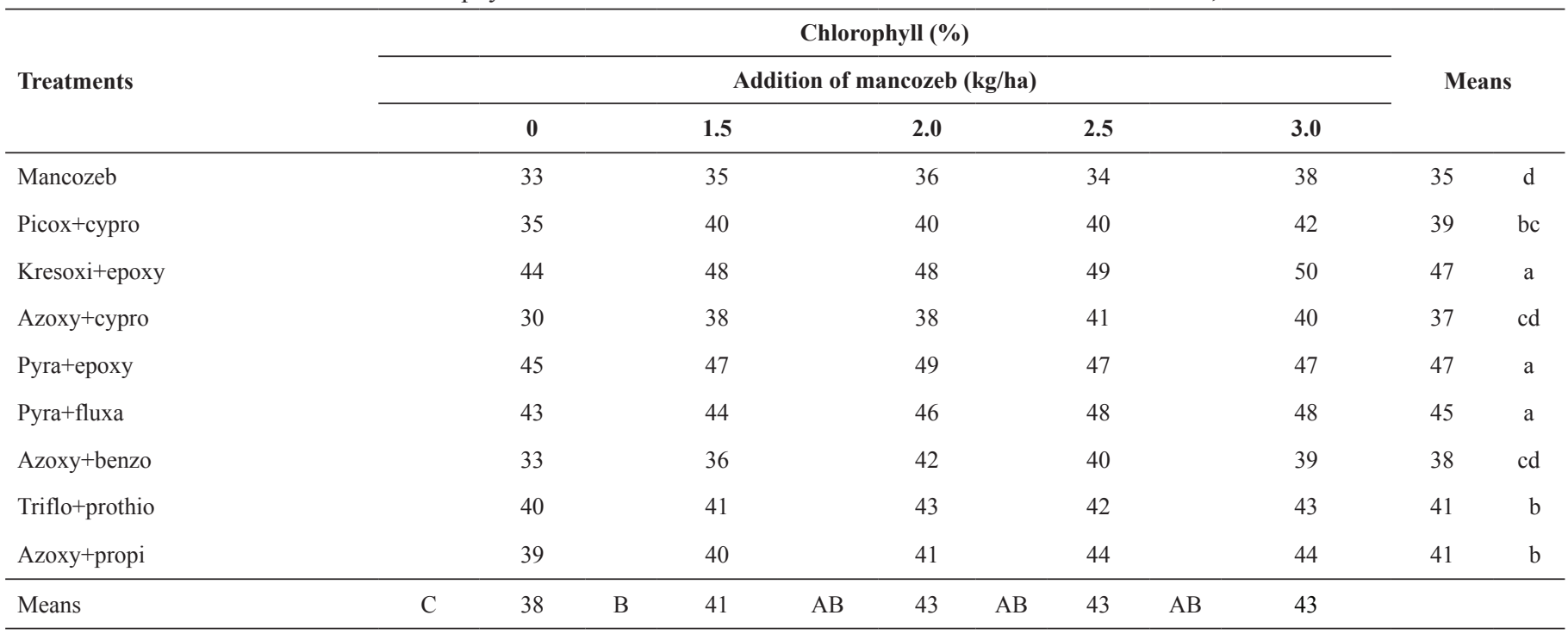

C.V. $(\%) 6.8$

Means of four replications, determined in 20 leaves per plot. Means followed by the same lowercase letter in the column and upper case in the line, do not differ by the Tukey's test at $5 \%$.

Table 4. Response of mancozeb addition to fungicide mixtures in wheat grain yield. Jadeíte 11, wheat cultivar. Passo Fundo, 2015

\begin{tabular}{|c|c|c|c|c|c|c|c|c|c|c|c|c|c|c|c|c|c|}
\hline \multirow{4}{*}{$\begin{array}{l}\text { Treatments } \\
\text { Mancozeb }\end{array}$} & \multicolumn{15}{|c|}{ Grain yield (Kg/ha) } & \multirow{3}{*}{\multicolumn{2}{|c|}{ Means }} \\
\hline & \multicolumn{15}{|c|}{ Addition of mancozebe (kg/ha) } & & \\
\hline & & 0.0 & & & 1.5 & & & 2.0 & & & 2.5 & & & 3.0 & & & \\
\hline & $\mathrm{B}$ & 2026 & $\mathrm{c}$ & A & 2431 & $\mathrm{C}$ & A & 2472 & d & A & 2441 & d & A & 2409 & d & 2342 & $\mathrm{f}$ \\
\hline Pycox+cypro & A & 2493 & $a b$ & A & 2483 & $\mathrm{Bc}$ & A & 2499 & $\mathrm{~cd}$ & A & 2647 & $\mathrm{~cd}$ & A & 2620 & $\mathrm{~cd}$ & 2530 & $\mathrm{e}$ \\
\hline Kresoxi+epo & $\mathrm{C}$ & 2723 & a & $\mathrm{BC}$ & 2796 & A & $\mathrm{AB}$ & 2946 & a & $\mathrm{AB}$ & 2943 & $\mathrm{a}$ & A & 3005 & a & 2852 & a \\
\hline Azoxy+cypro & A & 2492 & $\mathrm{~b}$ & $\mathrm{~A}$ & 2639 & $a b c$ & $\mathrm{~A}$ & 2629 & bed & A & 2636 & $\mathrm{~cd}$ & A & 2629 & $\mathrm{~cd}$ & 2599 & de \\
\hline Pyra+epoxy & B & 2700 & $a b$ & $\mathrm{AB}$ & 2788 & A & $\mathrm{AB}$ & 2805 & $\mathrm{ab}$ & A & 2918 & $a b$ & A & 2940 & $a b$ & 2803 & $\mathrm{ab}$ \\
\hline Pyra+fluxa & A & 2613 & $a b$ & A & 2601 & $a b c$ & A & 2721 & $a b c$ & A & 2706 & $\mathrm{bc}$ & $\mathrm{A}$ & 2751 & $\mathrm{bc}$ & 2660 & $\mathrm{~cd}$ \\
\hline Azoxy+benzo & A & 2570 & $a b$ & A & 2552 & $\mathrm{Bc}$ & A & 2604 & bed & A & 2607 & $\mathrm{~cd}$ & A & 2723 & $\mathrm{bc}$ & 2584 & de \\
\hline Trifl+prothio & B & 2691 & $a b$ & $\mathrm{AB}$ & 2701 & $\mathrm{Ab}$ & $\mathrm{AB}$ & 2765 & $a b$ & $\mathrm{AB}$ & 2756 & $a b c$ & $\mathrm{~A}$ & 2897 & $a b$ & 2728 & $\mathrm{bc}$ \\
\hline Azoxy+propi & A & 2635 & $a b$ & A & 2621 & $a b c$ & A & 2723 & $a b c$ & A & 2681 & $\mathrm{c}$ & A & 2760 & $\mathrm{bc}$ & 2665 & $\mathrm{~cd}$ \\
\hline Means & $\mathrm{C}$ & 2549 & & $\mathrm{BC}$ & 2624 & & $\mathrm{AB}$ & 2685 & & A & 2704 & & A & 2748 & & & \\
\hline
\end{tabular}

Means of four replications, followed by the same lowercase letter in the column and upper case in the row, do not differ by the Tukey test at $5 \%$.

Comparing the chlorophyll content in the treatment with cyproconazole + azoxystrobin (without mancozeb) $30 \%$ and epoxiconazole + methyl kresoxim (3.0 kg / ha mancozeb) $50 \%$, there was a $20 \%$ increase in chlorophyll content (Table 3 ).

Some mixtures containing strobilurins, and without mancozeb, such as methyl kresoxim (44\%) or pyraclostrobin (43\%), increased the chlorophyll content in wheat leaves (Table 3). The increase in chlorophyll content may influence grain yield regardless of fungicide control.

Analyzing the overall mean effect for mancozeb doses, grain yield was $2,549,2,624,2,685,2,704$, and $2,748 \mathrm{~kg}$ /ha for $0,1.5,2.0,2.5$, and $3.0 \mathrm{~kg} / \mathrm{ha}$, respectively. Regarding the fungicides, the lowest yield was obtained with the application of mancozeb alone with $2,342 \mathrm{~kg}$ / ha and the highest with the application of epoxiconazole + kresoxim methyl 3,005 kg/ha (Table 4). Comparing the grain yield in the control with that of kresoxim methyl + epoxiconazole the increase was $48.3 \%$.

Each $0.5 \mathrm{~kg}$ of mancozeb resulted in $44.079 \mathrm{~kg} / \mathrm{ha}$ grain yield increase $\left(y=44.079 x+2,568, \mathbf{R}^{2}=\mathbf{0 . 9 8}\right.$, where $\mathbf{y}=$ grain yield and $\mathrm{x}$ mancozeb $\mathrm{kg} / \mathrm{ha})$.

Rainfall was uneven distributed with an excess in July, when the crop was sown and a deficit in August, preventing the correct application of the second dose of nitrogen cover (Fig. 1). Rainfall accumulated during the wheat cycle (sowing on June 29 and harvest on November 23,2015 ) was $1,050 \mathrm{~mm}$. Considering the leaf blights control (94\%), 


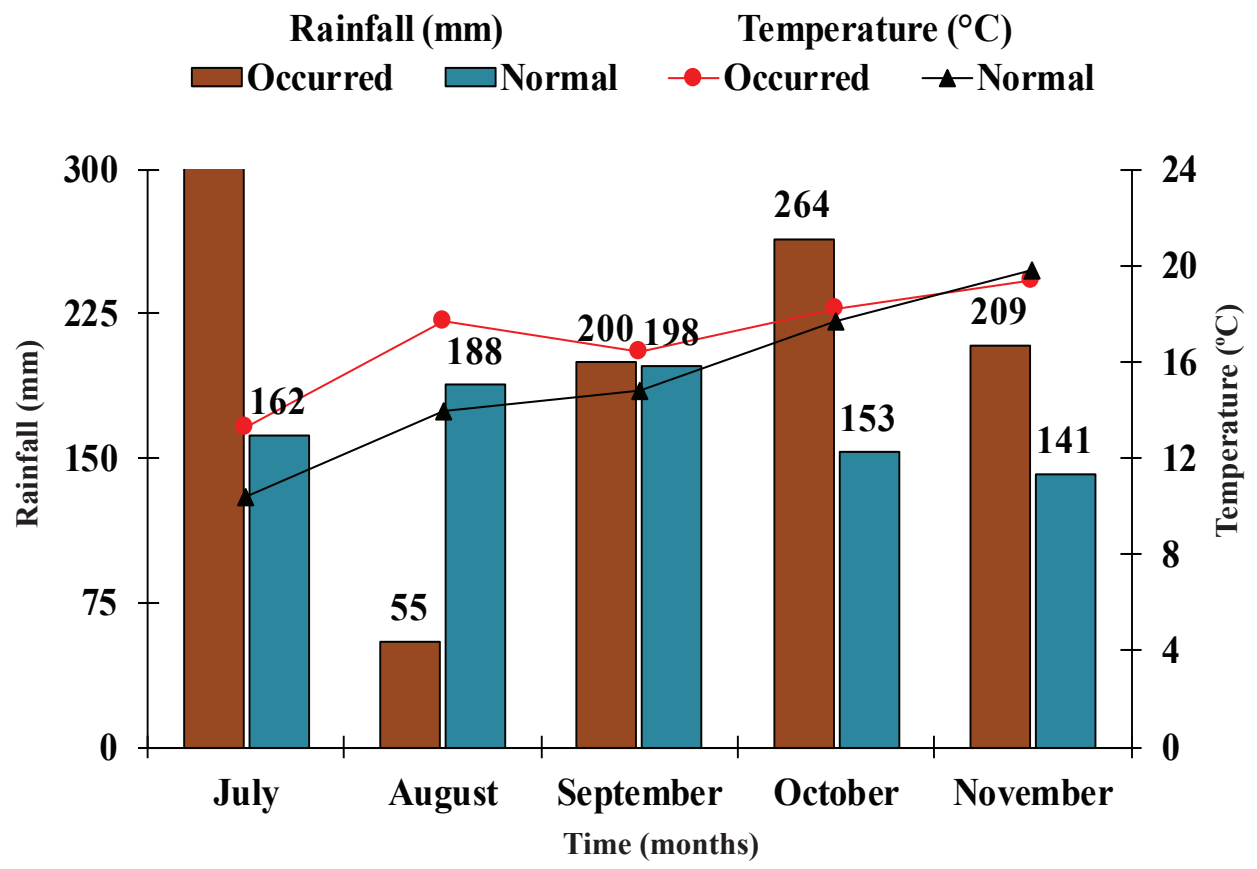

Figure 1.Rain and temperature fluctuation during the wheat cycle. Passo Fundo, 2015

it may be inferred that with this rain amount the protectant fungicide showed rain fastness.

\section{REFERENCES}

1. Conab. Acompanhamento da safra brasileira de grãos, V. 2 - Safra 2014/15. N. 12. Décimo Segundo Levantamento, setembro. 2015. Disponível em: <http://www.conab.gov.br/OlalaCMS/uploads/arquivos/15_09_11_10_42_03_boletim_graos_setembro_2015.pdf $>$. Acesso em: 02 nov. 2015. Colocar no modelo artigo de periódico indicando somente a parte utilizada

2. Fagan, E.B.; Dourado Neto, D.; Vivian, R.; Franco, R.B.; Yeda, M.P Massignam, L.F.; Oliveira, R.F.; Martins, K.V. Efeito da aplicação de piraclostrobina na taxa fotossintética, respiração, atividade da enzima nitrato redutase e produtividade de grãos de soja. Bragantia, Campinas, v.69, n.4, p. 771-777, 2010.

3. Gisi, U.; Cohen, Y. Resistance to phenylamide fungicides: A case study with Phytophthora infestans involving mating types and race structure. Annual Review Phytopathology, Palo Alto, v.34, p.549-572, 1996.

4. Minolta. Chlorophyll meter SPAD-502: instruction manual. Osaka: Minolta Co., 1989. 22 p.

5. Reis, E.M.; Floss, E.L. Efeito nutritivo de fungicidas carbamatos em trigo (TriticumaestivumL.). Summa Phytopathologica, Botucatu, v.6, p.116-22, 1980. Conferir citação no texto pois está com o número errado

6. Reis, E.M.; Casa, R.T. Doenças dos cereais de inverno: diagnose, epidemiologia e controle. Lages: Graphel, 2007. 176p.

7. Reis, E.M.; Silva, C.E.L.; Casa, R.T.; Medeiros, C.A. Decomposição dos restos culturais do trigo e sobrevivência saprofítica de Bipolarissorokiniana. Fitopatologia Brasileira, Brasília, DF, v.23, p.62-64. 1998.

8. Cunha, G.R.; Caierão, E. (Ed.). Reunião da comissão brasileira de pesquisa de trigo e triticale: informações técnicas para trigo e triticale: safra 2015, Brasília, DF: Embrapa, 2014. 229 p.

9. Tonin, R.F.B. Ocorrência de fungos em manchas foliares de trigo e sensibilidade de Drechslera tritici-repentis e $D$. siccans a fungicidas in vitro. 2012. Número de páginas. Tese (Doutorado em Agronomia) -Universidade de Passo Fundo, Passo Fundo.

10. Tonin, R.B.; Reis, E.M. In vitro mycelial sensitivity reduction of Drechsleratritici-repentis, isolates from wheat, to triazole fungicides. Summa Phytopathologica, Botucatu, v. , n. , p. , 2016.

11. Tonin, R.F.B.; Reis, E.M.; Danelli, A.L.D. Etiologia e quantificação dos agentes causais de manchas foliares na cultura do trigo nas safras 2008 a 2011. Summa Phytopathologica, Botucatu, v.39, n.2, p.102-109, 2013.

12. Stolte, R.E. Sensibilidade de Bipolaris sorokiniana e de Drechslera tritici-repentis a fungicidas in vitro. 2006. Número de páginas. Dissertação (Mestrado em Agronomia)-Universidade de Passo Fundo, Passo Fundo.

13. Zadoks, J.C.; Chang, T.T.; Konzak, C.F. A decimal code for the growth stages of cereals. Weed Research, Oxford, v.14, n.6, p. 415-421, 1974. 